\title{
TIKTOK TERHADAP VARIASI BAHASA KOLOKIAL PADA KALANGAN REMAJA INDONESIA (KAJIAN ETONOLINGUISTIK)
}

\author{
Andriyana, Daroe Iswatiningsih, Jenal Mahmud, Ode Evi Yulianti, Ton Thi Thuy Trang \\ Pendidikan Bahasa Indonesia \\ Pasca Sarjana Universitas Muhammadiyah Malang, Malang, Indonesia. \\ andriyana03@gmail.com
}

\begin{abstract}
ABSTRAK: Pada saat ini para remaja tidak dapat dilepaskan dari teknologi dan media sosial menjadi wadahnya. Di antaranya, Tiktok saat ini sangat gemari kalangan remaja, karena media sosial ini adalah tempat untuk mereka mengekspresikan dirinya dan juga sebagai tempat untuk berkomunikasi. Terdapat variasi atau ragam bahasa yang ada dalam menggunakan media sosial Tiktok. Keragaman tersebut hadir karena beberapa faktor - faktor sosial dan faktor situasi yang menyebabkan variasi bahasa dalam bermedia sosial Tiktok semakin beragam saat ini. Tujuan dari penelitian ini adalah analisis pengaruh Tiktok Terhadap Variasi Bahasa Kolokial pada remaja dan teman sejawat. Masalah yang diajukan dalam penelitian ini adalah "Bagaimana pengaruh tiktok pada bahasa kolokial remaja?" dan objek kajian adalah siswa SMA 1 Kejayan Jawa Timur dan Mahasiswa Universitas Kuningan Jawa Barat. Penelitian ini menggunakan metode campuran yaitu pendekatan kuantitatif dan kualitatif. Hasil dari penelitian ini adalah varasi bahasa Kolokial yang ditemukan dalam dalam media sosial Tiktok: Anomatope, Pronomina dan Kalimat.

KATA KUNCI: sosiolinguistik; variasi bahasa; variasi bahasa kolikial; aplikasi tiktok
\end{abstract}

Tiktok Against Colloquial Language Variation among Indonesian Adolescents (Ethnolinguistic Study)

\begin{abstract}
Nowadays young people cannot be separated from technology and social media. One of the social media platforms that has a major influence on Indonesian teenagers is Tiktok which is currently very popular with young people because this is a place for them to express themselves and also a place to interact with others. There are variants of the existing language and a new language formed when using Tiktok. This linguistic diversity occurs due to a number of social and situational factors that make the language variation on the social network - Tiktok more and more diverse. This research aims to analyze the influence of TikTok on colloquial change in adolescents and their peers. The problem posed in this study is "How does TikTok affect colloquial change among adolescents?" and the study subjects were third-class students on SMA 1 Kejayan East Java and students in Kuningan University, West Java. This research uses mixed methods research, namely quantitative and qualitative approaches. The results of this research are the colloquial variations found on the social network TikTok including onomatopoeia, pronouns, and sentences.
\end{abstract}

KEYWORDS: sociolinguistics, language variation, daily language variation (colicial), TikTok application

\begin{tabular}{llll}
\hline Diterima: & Direvisi: & Disetujui: & Dipublikasi: \\
$2021-01-21$ & - & $2021-01-27$ & $2021-03-28$
\end{tabular}

Pustaka : Andriyana, A., Iswatiningsih, D., Mahmud, J., Yulianti, O., \& Trang, T. (2021). Tiktok Terhadap Variasi Bahasa Kolokial pada Kalangan Remaja Indonesia (kajian Etonolinguistik). Fon : Jurnal Pendidikan Bahasa dan Sastra Indonesia, 17(1), 34-41. doi:https://doi.org/10.25134/fjpbsi.v17i1.3957

\section{PENDAHULUAN}

Pembahasan bahasa sebagai alat komunikasi manusia didasari oleh 12 hakikat bahasa yang salasatunya adalah bahasa itu dinamis. Dalam kedinamisan bahasa Chaer (2014) kehidupan di dalam masyarakat kegiatan itu tidak tetap dan selalu berubah, maka bahasa itu juga ikut berumah, menjadi tidak tetap, menjadi tidak statis. Karena itulah, bahasa itu 
disebut dinamis. Adanya kedinamisan ini membuat penelitian bahasa terus berkembang dan membuat beberapa faktor yang mempengaruhi bahasa layak diteliti.

Salah satu faktor yang ada tersebut adalah teknologi, dimana pada era industri 4.0 manusia dimanjakan oleh teknologi dan komputasi yang begitu berkembang termasuk pada media sosial yang digunakan manusia sebagai hiburan dan berkomunikasi. Untuk melihat pengaruh teknologi tersebut ilmu etnolingustik secara oprasional menurut Baehaqie, (2017) etnolinguistik dapat didefinisikan sebagai cabang linguistik yang dapat digunakan untuk mempelajari struktur bahasa dan/atau kosakata bahasa masyarakat etnis tertentu berdasarkan cara pandang dan budaya yang dimiliki masyarakat penuturnya dalam rangka menyibak atau mengungkap budaya masyarakat tersebut.

Pembahasan budaya dan bahasa dibahas dalam Abdul Chaer dari pendapat Edward Sapir dan Benjamin Whorf yang menyatakan bahwa bahasa mempengaruhi kebudayaan. Atau dengan lebih jelas bahasa itu mempengaruhi cara berpikir dan bertindak anggota masyarakat penuturnya (Chaer, 2014). Lebih lanjut pendapat Chaer (2014) ini mengatakan bahwa bahasa dan kebudayaan adalah dua hal yang tidak bisa dipisahkan. Maka hubungan yang ada dalam bahasa dan budaya atau kebudayaan saling mempengaruhi.

dalam telaah etnolinguistik terdapat tujuh unsur budaya yaitu (1) bahasa, (2) sistem pengetahuan, (3) organisasi sosial, (4) sistem peralatan hidup dan teknologi, (5) sistem mata pencaharian hidup, (6) siten Religi, setra (7) kesenian (Baehaqie, 2017). Erat kaitannya dengan budaya penggunaan teknolgi dan bahasa pada tahun 2021 ini penggunaan teknologi media sosial tiktok marak digunakan oleh kalangan remaja baik yang berada di jenjang sekolah menengah atau pun yang berada di jenjang sekolah tinggi.

Dalam penelitian ini penulis mengamati penggunaan bahasa pada masyarakat terpengaruhi penggunaan tiktok yang itu membuat mereka menggunakan bahasa-bahasa klokial dalam kehidupan sehari-hari. Bahasa kolokial ini adalah bariasi sosial yang digunakan dalam percakapan sehari-hari. Kata kolokial berasal dari kata colloquium (percakapan, konversasi). Jadi, kolokial berati bahasa percakapan, bukan bahasa tulis (Chaer \& Agustina, 2010). Di kehidupan sehari, penulis banyak sekali menjumpai bahasa-bahasa yang sering muncul dalam tiktok muncul dalam percakapan sehari-hari dalam kurun waktu tertentu bahkan menjadi bahasa yang lumrah digunakan.

Dalam penelitian pandangan tentang etnolingustik seringkali dipandang hanya pada segi budaya saja seperti penelitian yang dilakukan oleh Yani (2016) pada sistem religi dengan judul Leksikon Dalam Pernikahan Adat Melayu Riau: Kajian Etnolinguistik. Makrifah dan Fateah (2020) meneliti sistem religi dengan judul Istilah-Istilah Sesaji Ritual Sedekah Gunung Merapi di Desa Lencoh, Kecamatan Selo, Kabupaten Boyolali (Kajian Etnolinguistik). Wardoyo dan Sulaeman (2017) meneliti sistem peralatan hidup dengan judul Etnolinguistik Pada Penamaan Nama-Nama Bangunan di Keraton Yogyakarta. Sugianto (2015) meneliti bahasa dengan judul Kajian Etnolinguistik Terhadap Peribahasa Etnik Jawa Panaragan Sebuah Tinjauan Pragmatik Force. Sugianto (2016) meneliti sistem peralatan hidup dengan judul Kajian Etnolinguistik Terhadap Pakaian Adat Warok Ponorogo.

Dari penelitian-penelitian tersebut belum ada yang meneliti kaitan etnolinguistik dengan teknologi modern. Padahal jika berbicara tentang entografi 
itu sendiri maka bahasannya bukan hanya kebudayaan tapi juga pada budaya. Dan tiktok adalah budaya modern yang sekarang membudaya dan membudayakan bahasa lewat aplikasinya. Dan kajian bahasa keseharian tersebut dalam sosiolinguistik disebut bahasa kolokial.

Untuk meninjau relevansi penelitian ini, penulis meninjau beberapa penelitian yang berkaitan dengan analisis kolokial yang pertama adalah penelitian dari Muhidden dan Amran (2016) yang mengkaji trungkasi bahasa kolokial pada kalangan pelajar menemukan bahwa Dapatan kajian menunjukkan dalam bahasa melayu terdapat dua bentuk pemendekan yang digunakan dalam bahasa kolokial yaitu disilabik dan monosilabik. Penelitian kedua, kajian bahasa kolokial dikaitkan dengan bahasa jawa ditulis oleh (Asmara, 2015) yang membahas Basa-Basi Dalam Percakapan Kolokial Berbahasa Jawa Sebagai Penanda Karakter Santun Berbahasa. Dalam penelitian tersebut dijelaskan bahwa budaya masyarakat jawa dalam bahasa percakapan memiliki nilai sopan santun yang digunakan ketika bertemu lawan bicara. Penunjauan studi terdahulu pada kajian etnolingustik yang berkaitan dengan teknoligi media sosial baik itu facebook, instagram, twitter, tiktik, dan media sosial lainnya belum penulis temukan dalam berbagai jenis penelitian yang ada terutama penelitian bahasa Indonesia. Adanya kajian pengaruh tiktok terhadap bahasa kolokial di kalangan remaja Indonesia ini dapat penulis nyatakan satu kajian yang baru dan belum diteliti sebelumnya.

Adanya penelitian ini adalah satu buah analisis sosial dari pandangan etnolinguistik tentang hadirnya teknologi dengan melihat respon remaja pada aplikasi tiktok yang digunakan mereka dan teman sejawat. Setiap responden akan dipintai jawaban mengenai aplikasi tiktok dan pengaruhnya terhadap kebahasaan Indonesia yang secara sadar ataupun tidak sadar telah mempengaruhi teknologi.

\section{Metode}

Metode penelitian dalam penelitian ini adalah deskriptif kualitaitif. Tailor dalam Adapun tujuan dari penelitian deskriptif kualitatif adalah untuk menggambarkan, meringkas berbagai kondisi, berbagai situasi, atau berbagai fenomena realitas sosial yang ada di masyarakat yang menjadi objek penelitian dan berupaya menarik realitas itu ke permukaan sebagai suatu ciri, karakter, sifat, model, tanda, atau gambaran tentang kondisi, situasi, ataupun fenomena tertentu (Bungin, 2011).

Penelitian ini merumuskan dua permasalahan yaitu (1) tiktok dan budaya berbahasa dan (2) variasi bahasa kolokial dalam tiktok. Dari rumusan masalah tersebut peneliti menemukan dua objek kajian yang relavan menjadi partisipan yaitu siswa kelas 3 SMAN 1 Kejayan Pasuruan Jawa Timur dan Mahasiswa Universitas Kuningan Jawa Barat. Partisipan dipilih karena berada dilingkungan para peneliti dan meski ada perbedaan jenjang pendidikan namun keduanya masih tergolong dalam usia remaja.

Dalam tahap penelitian penulis melakukan langkah penelitian (1) Mengumpulkan data melalui google formulir (2) mereduksi data untuk penelitian (3) merepresentasikannya dalam analisis berdasarkan teori. Dari langkah penelitian tersebut penulis diharapkan akan maampu memecahkan masalah penelitian yang didalamnya mampu memberikan penerangan pada kedinamisan bahasa pada pengaruh tiktok dalam variasi bahasa kolokial di kalangan remaja Indonesia. 


\section{HASIL DAN PEMBAHASAN \\ Tiktok Dan Budaya Berbahasa}

Responden yang terkumpul

berjumlah 103 formulir isian yang terkumpul melalui google formulir dan terdiri dari dua intansi yaitu Universitas Kuningan Jawa Barat dan SMA 1 Kejayan Jawa Timur dengan jumlah partisipan paling banyak. Stekholder yang berpartisipasi adalah kalangan remaja berusia 16-22 tahun. Menurut menurut Badan Kependudukan dan Keluarga Berencana (BKKBN) dalam Diananda (2019) rentang usia remaja adalah 10-24 tahun dan belum menikah. Lebih lanjut tentang rentang usia remaja. Usia 17-21 tahun merupakan tahapan remaja lanjut yang memiliki karakter dirinya ingin menjadi pusat perhatian; ia ingin menonjolkan dirinya; caranya lain dengan remaja awal. Ia idealis, mempunyai cita-cita tinggi, bersemangat dan mempunyai energi yang besar. Ia berusaha memantapkana identitas diri, dan ingin mencapai ketidaktergantungan emosional (Diananda 2019). Karakter remaja tersebut juga terlihat dalam data yang kami temukan.

Data kualitataif yang ditemukan mengharuskan satu reduksi yang harus disajikan dalam pembahasan untuk mengefisiensi tulisan dalam artikel ini. Dari 103 respinden yang merespon kuisioner yang dibagikan dalam google formulir didapatkan data mengenai seberapa banyak responden yang bermain tiktok dan Intensitas responden dalam bermain tiktok. Tergambar dalam gambar 1 dan gambar 2 sebagai representasi para remaja dalam bermain tiktok untuk menilai seberapa besar tiktok itu digunakan.

Gambar 1. Diagram responden bermain tiktok

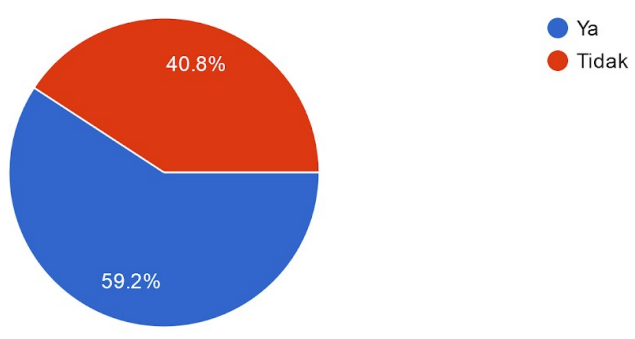

Gambar 2. Intensitas responden dalam bermain tiktok
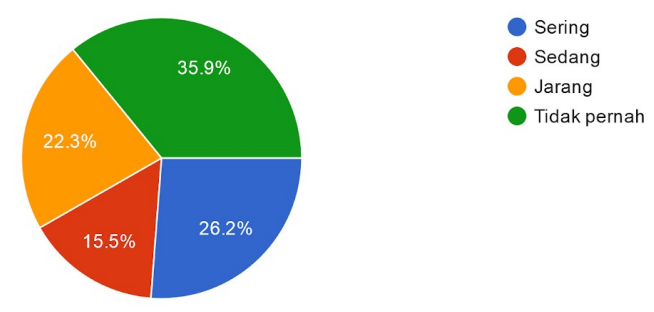

Jika melihat data statistik deskriptif pada gambar 1 terhihat data yang tidak bermain tiktok sebanyak $40.8 \%$ dan gambar 2 terlihat sebanyak 35.9\%. Selisih yang terjadi antara dua data ini merupakan satu hal yang unik namun tidak bisa dideskrpsikan secara statistik. Dalam data kualitatif yang didapatkam mereka yang $5.2 \%$ tersebut mengartikan pertanyaan pertama dengan barmain untuk membuat konten untuk di unggah dalam aplikasinya. Selanjutnya dalam pembahasan mengenai intensitas terlihat bahwa dari responden yang ada mereka merupakan pengguna aktif dan pengguna pasif. Pengguna pasif dapat dilihat pada gambar yang ketiga bahwa mereka yang sebanyak $48 \%$ masih menjawab pertanyaan berkaitan dengan kebahasaan yang itu bersumber dari penggunaan tiktok.

Dalam gambar 2 yaitu tabel statistik penggunaan bahasa yang bersumber dari tiktok dapat dilihat bahwa rentang pemakaian dari jumlah responden yang ada dapat dipresentasekan sedemikian 
rupa dan mampu merepresentasikan bahwa tiktok sangat mempengaruhi budaya berbahasa anak-anak remaja baik yang menggunakan tiktok maupun yang tidak menggunakan tikotk. Responden paling banyak terlihat pada "Tarik sis, Semongko" yang sering dipakai untuk beberapa konteks dalam penggunaanya di kehidupan sehari-hari. Kata-kata tersebut ternyata bisa diamati dalam kehidupan sehari-hari. Kata-kata lain selain itu juga dapat dilihat dari beberapa jawaban yang ditulis oleh responden.

Pada budaya berbahasa, kami dari tim peneliti mengajukan pertanyaan kepada responden "Jelaskan alasan bisa terpengaruh pada tiktok!". Beberapa jawaban dari mereka direduksi oleh penulis dan dapat merepresentasikan kenapa tiktok mampu mempengaruhi budaya berbahasa masyarakat. Diantanyanya adalah,

Hiburan

Media hiburan di era revolusi industry 4.0 yang merambah ke gawai terus berkembang sehingga tiktok menjadi alternatif bagi banyak kalangan untuk menghibur diri dalam aplikasi tersebut. Dan berikut adalah beberapa jawaban dari partisipan yang menyatakan bahwa mereka butuh hiburan,

1. "Gabut, bosen nonton youtube"

2. "karena dapat menghibur, mengisi waktu kosong, banyak cogan, banyak informasi, banyak hal hal yang membuat saya tersenyum bahagia"

3. "Karena videonya random dan dapat menghilangkan stres jadi bisa have fun hidup ini."

Interaksi sosial

Dalam penggunaan aplikasi tiktok, salasatu faktor pengaruh yang menyebabkan tiktok banyak digunakan adalah adanya interaksi sosial antar teman. Para partisipan mengemukakan beberpa alasan yaitu,

1. "Ngikutin temen"
2. "Ikutan teman teman yang muncul diberanda tiktok"

3. "diajak main tiktok sama teman"

Adapun alasan dari partisipan kenapa mereka bisa terpengaruh oleh tiktok bisa tergambar dalam beberapa jawaban berikut,

1. "Karena terbiasa liat konten tiktok yg lagunya bikin terngiang ngiang terus kalo denger lagu s[e]k[a]r[an]g j[a]d[i] mesti joget terus jadi ketagihan liat tiktok"

2. "Kalimatnya tidak panjang, mudah dicerna, dibarengi musik, menghibur."

3. "Karna ada hiburan, ada pembelajaran ,motivasi dan semuanya terbungkus dengan menarik.

\section{Variasi Bahasa Kolokial dari tiktok}

Dalam kehidupan sehari-hari bahasa kolokial digunakan dalam percakapan sehari-hari. Penulis mengajukan sebuah form yang berisi beberapa bahasa yang bisa dilihat dalam Gambar 3. Kata-kata tersebut adalah jejak pendapat yang dapat penulis rangkum dari setiap jawaban responden dengan angka dan presentasi secara deskriptif untuk menunjukan katakata atau kalimat apa yang sangat berpengaruh dalam kehidupan masyarakat.

Kata-kata yang disusun oleh penulis adalah sample dari beberapa kata yang polar di tiktok. Dalam formulir yang diberikan penulis memberikan perintah untuk menceklis daftar kata-kata yang disediakan lebih dari satu. Hal ini digunakan untuk bisa merepresentasikan seberapa banyak kata-kata itu terserap atau terpengaruh kedalam bahasa kolokial masyarakat.

Untuk melihat representasi kata-kata polular dalam tiktok, penulis menyajikan tabel berikut ini sebagai gambaran kepada pembaca. Kata dan representasenya dapat dilihat dalam gambar berikut sebagai tinjauan yang lebih komprehensip. 
Gambar 3 Diagram intensitas penggunaan kata-kata popular pada tiktok

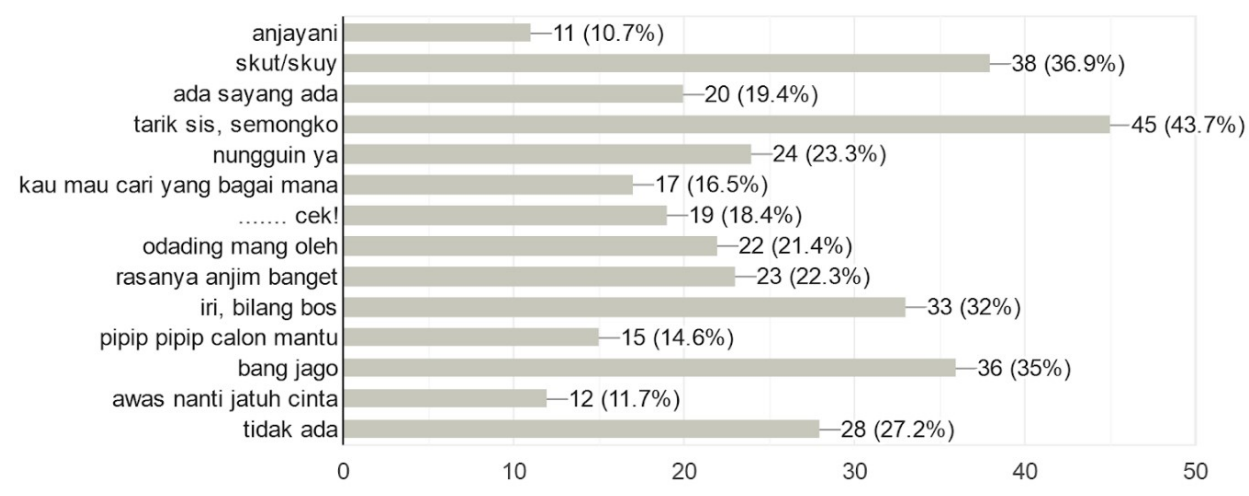

Dalam Gambar nomor 3 setiap kata dapat merepresentasikan seberapa banyak itu bisa terpengaruh dalam kehidupan sehari-hari. Dalam jawaban telihat jawaban paling banyak pada kalimat "tariksis, semongko" dan jawaban paling rendah pada anjayani”. Pada jawaban lain terlihat jelas bahwa memang tiktok sangat mempengaruhi. Bahkan angka representasi yang tidak terpengaruh atau menjawab "tidak ada" hanya 28 responden yang itu artinya mereka yang tidak menggunakan tiktok pun masih terpengaruh oleh kata-kata yang dipopularkan oleh tiktok.

Setelah memberikan formulir ceklisan, penulis menyodorkan kembali pertanyaan secara tertulis yang bisa di isi dengan sangat heterogen oleh setiap responden tentang apasaja yang di luar ceklisan digunakan oleh partisipan. Dari jawaban responden pada pertanyaan "Kata apa selain dalam pilihan yang digunakan dalam kehidupan sehari-hari yang bersumber dari tiktok?" Jawaban semakin heterogen dan makin banyak lagi katakata yang diakui oleh responden bahwa itu bersumber dari tiktok. Jawaban-jawaban tersebut kemudian direduksi oleh penulis dalam tabel berikut.

Tabel 1. Bahasa dari tiktiok

\begin{tabular}{|l|l|ll|}
\hline No & Bahasa Tiktok & Analisis & \\
\hline 1 & Aktif ya bund & Digunakan pada \\
\hline
\end{tabular}

\begin{tabular}{|c|c|c|}
\hline & & $\begin{array}{ll}\text { prilaku } & \text { yang } \\
\text { berlebihan } & \end{array}$ \\
\hline 2 & Oghey & Okey \\
\hline 3 & Papale papale & Anomatope lagu \\
\hline 4 & $\begin{array}{l}\text { kutukan } \\
\text { mantan masih } \\
\text { teringat jelas }\end{array}$ & $\begin{array}{l}\text { Untuk menjelaskan } \\
\text { kenangan yang } \\
\text { tidak bisa } \\
\text { dilupakan bersama } \\
\text { mantan kekasih }\end{array}$ \\
\hline 5 & sabi & $\begin{array}{l}\text { /bisa/ pertukaran } \\
\text { fonem }\end{array}$ \\
\hline 6 & Papichulo & Anomatope lagu \\
\hline 7 & $\begin{array}{l}\text { Bal bale bal } \\
\text { bale }\end{array}$ & Anomatope lagu \\
\hline 8 & $\begin{array}{l}\text { awas nanti } \\
\text { jatuh cinta. }\end{array}$ & $\begin{array}{l}\text { Untuk menunjukan } \\
\text { kelebian diri pada } \\
\text { lawan jenis }\end{array}$ \\
\hline 9 & Jinggo chis & Anomatope lagu \\
\hline 10 & Ogghey, & $\begin{array}{lr}\text { /oke/ adanya } \\
\text { perubahan dan } \\
\text { penambahan fonem }\end{array}$ \\
\hline 11 & bund & $\begin{array}{l}\text { Sapaan bagi lawan } \\
\text { bicara }\end{array}$ \\
\hline 12 & moms & $\begin{array}{l}\text { Sapaan bagi lawan } \\
\text { bicara }\end{array}$ \\
\hline 13 & sugar daddy & $\begin{array}{l}\text { Sebutan bagi laki- } \\
\text { laki berkepala tiga } \\
\text { yang menarik } \\
\text { perhatian } \\
\text { perempuan }\end{array}$ \\
\hline 14 & ngab, & $\begin{array}{l}\text { Sebutan bagi lawan } \\
\text { bicara }\end{array}$ \\
\hline 15 & $\begin{array}{l}\text { Ganteng doang } \\
\text { jemput depan } \\
\text { gang, }\end{array}$ & $\begin{array}{lr}\text { Satu } & \text { bahasa } \\
\text { percakapan yang } \\
\text { menjadi prokem di } \\
\text { masyarakat }\end{array}$ \\
\hline 16 & Hay gais's & Sapaan bagi lawan \\
\hline
\end{tabular}




\begin{tabular}{|l|l|l|}
\hline 17 & $\begin{array}{l}\text { adek kakak } \\
\text { edisen. }\end{array}$ & $\begin{array}{l}\text { Dicara } \\
\text { kakunakan ketika } \\
\text { melakukan aktifitas } \\
\text { bersamaan }\end{array}$ \\
\hline 18 & $\begin{array}{l}\text { Dino merah } \\
\text { meresahkan }\end{array}$ & Satu pros \\
\hline 19 & Hallo rek & $\begin{array}{l}\text { Sapaan bagi lawan } \\
\text { bicara }\end{array}$ \\
\hline 20 & $\begin{array}{l}\text { yakin gamau } \\
\text { sama ... }\end{array}$ & $\begin{array}{l}\text { Untuk menyatakan } \\
\text { kelebihan yang } \\
\text { dimiliki sebelum } \\
\text { ditunjukan }\end{array}$ \\
\hline
\end{tabular}

Dari semua data yang ada tentang bahasa kolokial. Penulis dapat mengkategorikan jenih kata atau kalimat yang ada serta penggunaan dan pengaruhnya menjadi tiga jenis yaitu Anomatope, Pronomina, dan Kalimat. Adapun dari tiga jenis itu berikut adalah penjelasannya.

Anomatope

Pada dasarya pengaruh tiktok adalah musik dan diksi yang digunakan dalam lagu-lagu pengiringya. Namun musikmusik itu memiliki irama yang dijadikan anomatope yang tidak memiliki arti namun sering sekali digunakan dalam bahasa kolokial yang bisa dilihat dalam tabel hasil analisis data bahwa ada beberapa data hasil temuan dari jawaban partisipan yang tidak memiliki arti sama sekali.

Pronomina

Dari jawaban-jawaban yang ada, peneliti melihat beberapa kata ganti orang atau pronominal dalam jawaban dari partisipan. Di tabel dapat dilihat hasil analisis menunjukan adanya kata ganti orang yang dipakai setiap para partisipan dalam keseharian.

Penggunaan kata ganti orang ini pada praktiknya seringkali mengalami perluasan makna, seperti kata "bund" dan "mom" yang merupakan pemendekan kata dari bunda dan momy dalam bahasa inggris. Dua kata yang bersinonim untuk ibu ini dipakai meluas bahkan melintasi gender yang artinya dibeberapa kasus itu dipakai juga pada laki-laki.

Dalam sapaan atau kata ganti orang, terlihat dalam data ada yang merupakan interferensi dari budaya jawa timur yaitu sebutan "arek" yang berarti kamu namun digunakan dengan pemendekan yaitu "rek". Selain interferensi kedalam pada kata "rek" terdapat juga interferensi keluar pada "gais's" yang pada dasarnya adalah kata "guys" yang berarti orang-orang dalam bahasa inggris namun dalam penyebutannya ada prubahan dan penambahan fonem.

Namun dalam pronominal ini ada juga kata yang dalam pembentukannya hampir tidak teridentifikasi tapi ternyata halt tersebut memiliki pola pergeseran fonem kata "bang" yang asal katanya abang di ubah oleh beberapa orang menjadi "ngab" yang itu adalah pergeseran fonem (/ab/ ke depan /ng/) dan pola yang sama ditemukan pada kata "sabi" yang itu bisa tergolong menjadi bahasa slang.

Kalimat

Dalam analisis kalimat yang bersumber dari aplikasi tiktok tidakbegut banyak yang berubah atau tidak ada pola tertentu yang mempengaruhi proses katakatanya. Hanya saja setiap kalimat yang muncul di tiktok selalu bersumber dari lirik lagu seperti "kutukan mantan masih teringat jelas", "awas nanti jatuh cinta", dan "kamu mau cari yang bagai mana". Kata-kata tersebut bersumber dari lagulagu yang menjadi latar musik dalam tiktok.

Beberapa kalimat-lain atau yang tersaji dalam data rata-rata adalah jargon yang dibuat terus menerus dan berulang dalam konten-konten tiktok sehingga mempengaruhi pola ucap masyarakat. Contohnya saja "odading mang oleh" yang itu adalah jargon dari Ade Londok yang mempromosikan gorengan yang ia makan viral dan kemudian banyak ditiru masyarakat tiktok. Hal yang sama terjadi 
pula pada "ganteng dong jemput cewe depan gang", "sugar dady", dan "dino Merah meresahkan".

\section{KESIMPULAN}

Aplikasi tiktok sangat berpengaruh pada kehidupan sosial dan masyarakat yang itu sudah membudaya dalam keseharian masyarakat Indonesia. Penggunaan aplikasi tiktok tersebut mempengaruhi bahasa keseharian atau bahasa kolokial sebagai kalimat yang sehing digunakan dalam kehidupan seharihari. Kajian etnolinguistik pada tataran teknologi dapat menyimpulkan bahwa sosial media tiktok sangat mempengaruhi prilaku bahasa masyarakat terutama di kalangan remaja.

Penulis melihat bahwa dampak bahasa yang terjadi pada penggunaan aplikasi tiktok sangat berpengaruh besar sehingga perlu adanya pengarahan pada penggunaan bahasa atau sosialisasi di dalamnya. Pengaruh tiktok yang sangat signifikan tersebut harus bisa dimanfaatkan juga untuk sosialisasi bahasa yang baik dan benar.

\section{DAFTAR PUSTAKA}

Asmara, R. (2015). Basa-Basi Dalam Percakapan Kolokial Berbahasa Jawa Sebagai Penanda Karakter Santun Berbahasa. Transformatika.

Baehaqie, I. (2017). Etnolingustik Telaah Teoretis dan Praktis (cetakan ke). Yuma Pressindo.

Bungin, B. (2011). Penelitian Kualitatif: Komunikasi, Ekonomi, Kebijakan Publik, Dan Ilmu Sosial Lainnya. In Kencana.

Chaer, A. (2014). Linguistik Umum (Edisi Baru). PT Rineka Cipta.

Chaer, A., \& Agustina, L. (2010). Sosiolinguistik: Pengantar Awal. In
Jakarta: Rineka Cipta.

Diananda, A. (2019). PSIKOLOGI REMAJA DAN PERMASALAHANNYA. Journal ISTIGHNA. https://doi.org/10.33853/istighna.v1i 1.20

Makrifah, S., \& Fateah, N. (2020). IstilahIstilah Sesaji Ritual Sedekah Gunung Merapi di Desa Lencoh, Kecamatan Selo, Kabupaten Boyolali (Kajian Etnolinguistik). Sutasoma: Jurnal Sastra Jawa. https://doi.org/10.15294/sutasoma.v7 i2.36667

Muhidden, Z., Amran, N., \& Optimaliti, T. (2016). Penggunaan Trunkasi Bahasa Kolokial Truncation Use Language Colloquial. 128-153.

Sugianto, A. (2015). Kajian Etnolinguistik Terhadap Peribahasa Etnik Jawa Panaragan Sebuah Tinjauan Pragmatik Force. Seminar Nasional PRASASTI II "Kajian Pragmatik Dalam Berbagai Bidang."

Sugianto, A. (2016). KAJIAN ETNOLINGUISTIK TERHADAP PAKAIAN ADAT WAROK PONOROGO. ARISTO. https://doi.org/10.24269/ars.v3i1.8

Wardoyo, C., \& Sulaeman, A. (2017). Etnolinguistik Pada Penamaan Nama-Nama Bangunan di Keraton Yogyakarta. Al-Tsaqafa: Jurnal Ilmiah Peradaban Islam. https://doi.org/10.15575/altsaqafa.v14i1.1791

Yani, J. (2016). LEKSIKON DALAM PERNIKAHAN ADAT MELAYU RIAU: KAJIAN ETNOLINGUISTIK. Jurnal Ilmu Budaya. https://doi.org/10.31849/jib.v12i2.11 11 